\title{
Naxis
}

Katarzyna Wądolny-Tatar

\section{Maskowanie gatunku. Kołysanka w liryce współczesnej}

$\mathrm{W}$

spółczesne językoznawstwo, zwłaszcza etnolingwistyka, w ustalaniu cech gatunków folklorystycznych bierze pod uwagę przynależność tekstu do określonych sytuacji niecodziennych (np. wesele, pogrzeb) i codziennych (np. wypasanie bydła, usypianie dziecka). Pojęcia genologiczne traktowane są jak kategorie formalne, poznawcze, funkcjonalne i aksjologiczne. Jerzy Bartmiński stwierdza:

Opis gatunków folkloru jest z natury swojej nastawiony na wydobycie cech utrwalonych społecznie, konstytuujących wzorce wypowiedzi. Opis taki wymaga uwzględnienia cech istotnych. Równocześnie winny to być cechy maksymalnie proste. Funkcjonują one na zasadzie obecności kontrastującej z nieobecnością (np. uwikłanie w sytuację wobec braku takiego uwikłania), równorzędności pewnych jakości w porównaniu z innymi (np. związek ze zwyczajami Bożego Narodzenia, ze zwyczajami Wielkiejnocy, z sobótką), wreszcie na zasadzie stopnia nasilenia pewnej jakości (np. długość tekstu). Gatunkowi może przysługiwać kilka cech charakterystycznych. Zwykle któraś z nich dominuje. Genologia współczesna akcentuje wielotreściowy, typologiczny, otwarty charakter pojęcia gatun$\mathrm{ku}$, włącza w definicję cechy właściwe wszystkim egzemplarzom danego gatunku [...], a także cechy właściwe tylko egzemplarzom typowym, normalnym $[\ldots]^{1}$.

1 J. Bartmiński, Gatunki folkloru, w: Akty i gatunki mowy, seria Wspótczesna polszczyzna. Wybór opracowań, tom 3, red. J. Bartmiński. S. Niebrzegowska-Bartmińska, J. Szadura, Lublin 2004, s. 170. 
Lubelski badacz porządkuje cechy gatunków folklorystycznych, co daje możliwość stworzenia dalszej klasyfikacji tekstów. Uwzględnia między innymi uwikłanie tekstu w sytuację lub brak takiej zależności, sytuacyjność zaś klasyfikuje według kryteriów określających jej zwyczajowość, obrzędowość, okolicznościowość i dalej — konkretne jakości tych sytuacji (kolędowanie, zapusty, zakończenie żniw, taniec, modlitwa i wiele innych). Decydujące znaczenie ma oczywiście mówiony lub śpiewany charakter przekazu, czyli obecność w nim lub brak kodu muzycznego i podobnie — obecność lub brak kodu somatycznego, co oznacza zaprojektowane w tekście gesty i ruch. Z innych, uwzględnionych przez językoznawcę wyróżników, trzeba przypomnieć: formę wierszowaną lub prozatorską tekstów, intencje wewnętrzne przekazu, prawdziwość lub fikcyjność treści, poetykę i temat. Na podstawie cech dystynktywnych odbywa się identyfikacja i kwalifikacja poszczególnych tekstów.

Ludowa kołysanka należy do przekazów okolicznościowych, wiąże się z codziennym działaniem praktycznym, ma charakter śpiewany, zawiera więc kod muzyczny, a także somatyczny, ze względu na zawarty w niej projekt ruchu — kołysania, huśtania. Ma też zwykle formę wierszowaną i silnie rytmizowaną oraz cechuje się wyraźną intencjonalnością. Kwestie prawdziwości czy fikcjonalności treści, poetyka i tematyka są tu drugorzędne i traktowane fakultatywnie. Wszystkie cechy pełnią funkcję utożsamiającą i odróżniającą, szczególnie w odniesieniu do Arystotelesowskiego statystycznego modelu genologii, bo w dynamicznym i bardziej płynnym ujęciu (na przykład prototypowym modelu Eleonor Rosch, na którym opierają się kognitywiści) cechy te pozwalają lokować dany przekaz w centrum bądź na peryferiach gatunkowej sieci radialnej i widzieć go na tle innych realizacji.

Kołysanka użyta jako forma w poezji współczesnej traci swoje rzeczywiste sytuacyjne referencje, które zachowywała w literaturze ludowej czy nawet w literaturze dla dzieci (chociaż w tej ostatniej przyjmuje ona także interesujące formy, wykorzystuje różne akty mowy, ma intertekstualny charakter), ale także i na tym gruncie kołysanka przekształca się z użytkowego gatunku mowy w gatunek literacki. Można powiedzieć, że sytuacyjność ulega semantycznej amplifikacji, „usypiany” może być bowiem ktokolwiek lub cokolwiek, przy czym sen bywa traktowany tu również ogólnie i metaforycznie jako odmienny stan świadomości, oszołomienie, znieczulenie, zmęczenie, śmierć, ale też istnienie w innej rzeczywistości, złudzenie i iluzja. Przeniesienie gatunku mowy w sferę literacką oznacza zwiększony stopień metaforyczności przekazu pod każdym względem. Trudno tu więc zdecydowanie mówić o łamaniu konwencji, skoro zmienia się środowisko funkcjonowania tekstu, trzeba uwzględnić raczej koncepcję transgatunkowości².

2 Zob. B. Witosz, Genologia lingwistyczna. Zarys problematyki, Katowice 2005; H. Grzmil-Tylutki, Gatunek $w$ świetle francuskiej teorii dyskursu, Kraków 2007; I. Loewe, O pojęciu transgatunku. Studium przypadku, w: Styl a semantyka, red. I. Szczepankowska, Białystok 2008, s. 159-166. 
W liryce współczesnej (adresowanej do dojrzałego odbiorcy) daje się zaobserwować naruszenie wyprowadzonego z folkloru wzorca, co przejawia się w niezgodności intencji wypowiedzi z jej strukturą, eliminacji czy transpozycji niektórych cech. Mamy także do czynienia $z$ „fuzją form”, powstają interesujące kontaminacyjne odmiany kołysanki. Wiele z nich mocno zakłóca kołysankowy kod, przekształcając go punktowo albo holistycznie, powstaje kołysanka-tren, kołysanka-lament, kołysanka-haiku. Literackie mutacje gatunku są już przejawem gry z konwencją, o której — łącząc perspektywę literaturoznawczą i językoznawczą — pisze Bożena Witosz:

Łamanie konwencji — w przypadku tekstu literackiego — jest odczytywane jako manifestacja wzmożonej świadomości gatunkowej, której tekst oczekuje także po stronie kulturowej kompetencji czytelniczej. Normy wypowiadania się są traktowane jako krepujący gorset zagrażający indywidualnym procesom twórczym. Natomiast w obrębie komunikacji pozaestetycznej nierespektowanie regul gatunku interpretowane jest jako wynik niedostatecznej kompetencji komunikacyjnej, która zakłóca interakcję ${ }^{3}$.

W pewnym sensie inaczej pojmowana jest też w kołysance literackiej okazjonalność, ponieważ gatunek staje się okazją do autoprezentacji podmiotu, zasygnalizowania antynomiczności świata, genologicznego kamuflażu, chociaż jego związek z tematyką „okołosenną" nadal istnieje.

Kołysankę-tren spotykamy w twórczości Eugeniusza Tkaczyszyna-Dyckiego. Jego tom Piosenka o zależnościach i uzależnieniach, nagrodzony literacką Nike w roku 2009 roku, trzeba by potraktować jako dość jednorodny cykl utworów. Idąc też za spostrzeżeniami Joanny Orskiej, można uznać skłonność do cyklizacji za cechę tej poezji (ze względu na konstrukcję podmiotu, numerację wierszy, ich tematykę, powtarzające się w nich motywy): „[...] jego wiersze przypominają raczej zagadki w formie zgrzebnych, udających niesymboliczne obrazków, snujących się przez kilka utworów poetyckich narracji, opowieści niesamowitych czy wypominek po zmarłych." ${ }^{4}$

W skład owego cyklu wchodzi wiersz XXI. Kotysanka:

śpij kasztelanie Aleksandrze

Dzieduszycki śpij nienaruszenie

\footnotetext{
3 B. Witosz, Gatunek — sporny (?) problem wspótczesnej refleksji tekstologicznej, w: Sporne i bezsporne problemy wspótczesnej wiedzy o literaturze, red. W. Bolecki, R. Nycz, Warszawa 2002, s. 281.

4 J. Orska, Kresy tożsamości. Na podstawie poezji Eugeniusza Tkaczyszyna-Dyckiego, w: Krainy utracone i pozyskane. Problem $w$ literaturach Europy Środkowej, red. K. Krasuski, Katowice 2005, s. 257. Autorka analizuje twórczość Dyckiego w oparciu o Derridiański model literatury.
} 
i nie obawiaj się że jestem

Dycki z tych co niepokoją sobą

o tak śpij kasztelanie Aleksandrze

Dzieduszycki synu kasztelanicowy

pana Jerzego: niechaj ci się przyśni

Lubaczówka której wody obejmują

twoje i moje kości i póki piszę

wiersze nie będzie temu końca ${ }^{5}$

Poeta korzysta z utrwalonej w tradycji metafory „śmierć to sen”, sankcjonującej mówienie o śmierci w kategoriach snu — i kołysanka staje się jednocześnie trenem. Interesujący jest historyczny sztafaż utworu i wpisany weń szczegół geograficzny. Wiersz można uznać za konterfekt genealogiczny, oprócz imienia i nazwiska „śpiącego” znany jest tytuł szlachecki, wynikający ze sprawowanej w rodzie funkcji, wspomniane zostaje imię ojca bohatera literackiego. Lubaczówka nie tylko historycznie umiejscawia egzystencję postaci, ale także — jako rzeka pamięci, a nie zapomnienia — symbolicznie łączy obszary i osoby. Ostatnie wersy można właśnie traktować jak szczególną obietnicę trwania i zapamiętania. W ogóle wspomniany tom rejestruje próbę przezwyciężenia kresu (istnienia czy tożsamości), rozpoczyna go poetycka modlitwa:

daj mi słowa abym kres

nazwał umiejętnie kresem

i w nim tańczył (żebym

z radością zatoczył koła

które będą kołami nicości

i moimi kresami) $[\ldots]^{7}$

Znamienne, jak w tym kontekście przydatna w interpretacji okazuje się diagnoza Orskiej:

w wierszach Dyckiego wyższa instancja, rekonstruowana w wierszu „centralna” tożsamość, podporządkowała sobie podróżującego bohatera; wo-

5 E. Tkaczyszyn-Dycki, Piosenka o zależnościach i uzależnieniach, wyd. II skorygowane, Wrocław 2009, s. 25.

6 Ten typ metafory rozwijam w: K. Wądolny-Tatar, Metaforyka oniryczna w liryce Młodej Polski, Kraków 2006.

E. Tkaczyszyn-Dycki, I., w: idem, Piosenka o zależnościach i uzależnieniach..., op. cit., s. 5. 
bec tego, jakkolwiek inny, nie może on ruszyć się dalej niż mucha na nitce. Zatacza kręgi, pozostając w obrębie tych samych, rozpoznanych już problemów, zamyka się na przyszłość bycia, także wplatany w meandry tekstu, odnajduje jedynie martwy tekst właśnie, nigdy zaś nie sięga po różnicę, nie podąża jej śladem. Na kresach Dyckiego znajdujemy tylko kres; to on pozostaje celem wędrówki, nie zaś granicą do przekroczenia. Dlatego wiersze Dyckiego, dopóki determinowane będą taką konstrukcją podmiotu, pozostaną zawsze jak dreptanie w miejscu. Dreptanie na kresach ${ }^{8}$.

Różnica oznaczałaby wytrącenie ze stałego rytmu, nową amplitudę wychyleń i oddaleń, a tak utwory Tkaczyszyna-Dyckiego pozostają specyficznymi „w-kołysankami”, zawiera się w nich usilność poszukiwań tożsamości „krążącego” podmiotu. Dziejowość w poezji tego twórcy oznacza potrzebę ustalenia genealogii rodu, powrotu do prapoczątku, stanowiącego źródło ,ja”. Komunikowanie sobą przekłada się na znajomość własnej szeroko pojętej przeszłości, orientację w historii antenatów. Kołysanka spełnia tu doskonale funkcję pierwotnej inicjacji komunikacyjnej. Anna Pytlewska zwraca uwagę na charakterystyczną dla autora Dziejów rodzin polskich poetycką technikę operowania cyklem, serią, siecią i na oscylowanie między tekstualnością a egzystencją ${ }^{9}$.

Z motywem śmierci lączą się epigramatyczne kołysanki Wojciecha Kassa. Dwa niewielkie teksty umieszczone na sąsiednich stronach tematycznie i graficznie tworzą swoisty dyptyk, śmierć utrzymuje tu swoje senne kolokacje:

Piszę o śmierci

dla śmierci,

śnię muzykę kości

lodu w szklance

a wolałbym rzepak, ugier. ${ }^{10}$

Piszę o śmierci

przeciw śmierci.

Czasem zasypia mi

na kolanach. ${ }^{11}$

8 J. Orska, Kresy tożsamości..., op. cit., s. 264-265.

9 Zob. A. Pytlewska, Cykl, seria, sieć. Metody poetyckie Eugeniusza Tkaczyszyna-Dyckiego, w: Polski cykl liryczny, red. K. Jakowska, D. Kulesza, Białystok 2008, s. 427-438.

${ }_{10}$ W. Kass, Wiry i sny, Sopot 2008, s. 36.

11 Ibidem, s. 37. 
Lapidarna struktura i ślad epifanii zbliża utwory do haiku. Komizm ujawnia się w zderzeniu tytułów, w których zawiera się deklaracja gatunkowa i wskazanie na osobowoprywatny aspekt (Kotysanka Andrzeja Sosnowskiego, Kotysanka Wojciecha Kassa), z treścią wierszy. Całość utworów odsyła zresztą do jakiegoś programu poetycko-egzystencjalnego twórców. Kołysanka oznacza tu stałe zajmowanie się daną kwestią, powracającą myślą, nieustanne zmaganie się z czynnością, tematem. Umieszczenie w tytule nazwisk poetów powoduje personalny charakter wypowiedzi, jest jakby wskazaniem na konkretne „ja” mówiące. Autotematyzm ujawnia się już w sytuacji początkowej, wspólnej dla obu kołysanek, dalsze wersy przynoszą zróżnicowane rozwinięcie. Strategia: „Piszę o śmierci/ dla śmierci” w jednym z wierszy stanowi przeciwwagę tej rozpoczynającej drugi wiersz: „Piszę o śmierci/ przeciw śmierci”, pierwsza wstępnie deklaruje akceptację stanu rzeczy, druga opiera się na antagonistycznym działaniu. Efekt twórczych przedsięwzięć jest różny, jakby odwrotny wobec przyjętego planu.

Kołysanką-traktatem filozoficznym można nazwać wiersz Zbigniewa Herberta (chociaż Dariusz Pawelec mówi w przypadku tego utworu o formule elegijnej ${ }^{12}$ ). Istnienie człowieka we współczesnym świecie, jego postrzeganie i doświadczanie rzeczywistości ma potwierdzać trafność badań starożytnych uczonych, którzy stwierdzili kurczenie się wszechświata, i pośrednio może stanowić dowód na uniwersalizm ludzkich losów. "Ja" mówiące dysponuje wiedzą tajemną, wie bowiem to, co wiedzą ci, którzy „teraz łagodnym stokiem idą tam gdzie wszyscy idą”"13. Na przedwiedzę składają się aksjomaty zgromadzone w wierszu w postaci wyliczeń o synekdochicznym charakterze, prawdy dotyczące zmieniającego się u człowieka poczucia czasu, wartościowania rzeczy, dystansu wobec spraw i osób. Szereg wyodrębnionych graficznie, jakby osobno postawionych kwestii („-- między ziewnięciem w grudniu a sierpniową drzemką/ mija zaledwie chwila bez zdarzeń i tęsknoty”; „- coraz mniej listów podróży zdziwienia”; „w pustych pokojach kurz zasiadł i pisze pamiętniki”) wskazuje kierunek i skalę zmian - ubywanie, zmniejszanie. Powtórne przywołanie w finale utworu starożytnego doświadczenia i jego wyniku, opisanego teraz jednym wersem, w połączeniu z konkluzją daje efekt rekursywności typowy dla kołysanki i uwydatnia puentę: „Co roku Wieczna Lampa spala mniej oliwy/ Tak zacny wszechświat układa nas do snu.” Zmniejszona atrakcyjność świata, szybciej płynący czas ułatwia zasypianie na wieczność.

Wyraźne cechy kołysanki ma Lament matki na Zamojszczyźnie Zbigniewa Jerzyny. Zdefiniowana już w tytule osoba mówiąca i dopisek autora zawierający datę (rok 1943) pozwala ustalić wydarzenia, o jakich mowa w tekście:

12 D. Pawelec, Kotysanka, w: idem, Od kotysanki do trenów. Z hermeneutyki form poetyckich, Katowice 2006, s. $28-56$.

${ }^{13}$ Z. Herbert, Kotysanka, w: idem, Wiersze zebrane, oprac. R. Krynicki, wyd. I - dodruk, Kraków 2008, s. 477. 
Moje dzieciątko w śmiertelnym wagonie

Przez Polskę jedzie - widzę ślepe tory.

Chyba je dobrze karmią w drodze mrozem.

Chyba je dobrze strutą wodą poją.

Chyba je dobrze światełkami bawią

$\mathrm{Na}$ wielu stacjach — na krzyżowej drodze.

Moje dzieciątko w śmiertelnym wagonie.

Już ta kołyska trumienką się stała.

Luli, dzieciątko moje, szkieleciku,

Lulaj — mamusia twoja oszalała $-{ }^{14}$

Tragedia matki, której odebrano dziecko, jest przyczyną jej obłędu. Utwór także łączy bliskie, zakorzenione w kulturze konotacje, wynikające z metaforycznego utożsamienia snu i śmierci. Powtórzenia wskazują na lamentacyjny charakter wypowiedzi, a emocjonalność wyznania — na zaburzoną świadomość ,ja”. Możliwa wydaje się też romantyczna kontekstualizacja utworu (szczególnie w aspekcie patriotyczno-martyrologicznym, mimo zmienionych realiów historycznych), na którą pozwala opis cierpienia matki, jej obłąkania, postać dziecka wywożonego przez oprawców w „śmiertelnym wagonie".

Dzieciom Zamojszczyzny poświęca uwagę w swojej twórczości również Teresa Ferenc. Jej osobiste przeżycia modelują obrazy poetyckie w wierszach, w których powracają przejmujące wizje i echa wydarzeń z 1943 roku. Ferenc była ich świadkiem jako kilkuletnia dziewczynka. W jednym z utworów poetki bezpośredni kontakt kobiety z dzieckiem-wnukiem rodzi tkliwość i czułość wobec małego chłopca, ale jednocześnie uruchamia traumatyczne doświadczenia (choć enigmatycznie sugerowane w liry$\mathrm{ku}$ ), wzmacnia potrzebę ochrony dziecka i jego snu przed światem:

— Jesteś w moich czułych rękach

Mam bryłkę samej siebie

ulepioną ugniecioną z bożą męką

Moje usta nakarmiono szaleństwem

aż Bóg się skrzywił

Aniołowie zachodzą w piekące pestki

Szatan wyrósł bujnie

lecz zaraz się zapadł

$[\ldots]$

${ }^{14}$ Z. Jerzyna, Lament matki na Zamojszczyźnie, w: idem, Poezje wybrane, wstęp i wybór autora, Warszawa 1984, s. 85 . 
Śpij synu

pij

słodycz mojej krwi ${ }^{15}$

We wnętrzu osoby mówiącej dokonuje się prawdziwa psychomachia, a kontakt z dzieckiem ostatecznie wyzwala siły dobra. Kołysanka przekształca się w opowieść „o sobie”. Uporanie się z przeszłością jest chwilowe i oznacza okresowe, okazjonalne (jak w momencie zasypiania dziecka) wyciszanie wspomnien ${ }^{16}$.

Bardziej skomplikowaną konstrukcję ma wiersz Anny Janko Uktadanie do snu, pośrednio przywołujący doświadczenia, o których wyżej była już mowa. Zestawienie obu tekstów możliwe jest ze względu na pokrewieństwo obu autorek i realizujący się w twórczości dialog: matka - córka. Kontekstowe czytanie ich twórczości mogłoby przynieść interesujące literacko, a także antropologicznie efekty. U Janko mamy do czynienia z odmową kołysanki, bo nie zostają spełnione podstawowe założenia sytuacyjne:

Nie zaśpiewam ci

w drugą stronę kołysanka nie śpiewa

Nie powiem miód i wino piłam — nie byłam

i nie mam nic do zabawy

mam tylko wstyd u twoich oczu

i nasze cztery ręce stare

Opowiem ci za to Była śliczna owoc człowieka

na ramieniu ojca

w niebieskiej sukni prosto w okno weszła

pokój był żółty ja tam stałam gotowa

na przyjęcie jej obrazu Tak wschodziła

moja matka

Zaśnij $^{17}$

15 T. Ferenc, Do wnuka, w: eadem, Psalmy i inne wiersze dawne i nowe, Gdańsk 1999, s. 111.

16 Ferenc daje temu wyraz w utworze Psalm prowadzonej na rzeź z tomu pt. Wypalona dolina (1979), polemicznym wobec znanego wiersza Tadeusza Różewicza Ocalony. Do wspomnianego utworu Różewicza nawiązuje również Józef Baran, dedykując poecie swój wiersz Mam dwadzieścia pięć lat: „mam dwadzieścia pięć lat/ a moje życie zamyka się w siedmiu dniach/jeden z tych siedmiu dni/ jest dniem moich urodzin/ jeden z tych siedmiu dni/ będzie dniem mojej śmierci”. Wiersz Barana podkreśla cykliczność zjawisk i procesów, eksponuje perspektywę zamknięcia egzystencji, jej niezmienność, odbijającą się także w codziennej monotonii. W zakończeniu utworu czytamy: „a siedem nianiek tygodnia kołysze mnie/ i zawodzi wciąż jedną i tę samą kołysankę" (J. Baran, Mam dwadzieścia pięć lat, w: idem, Wiersze wybrane, Warszawa 1984, s. 159).

17 A. Janko, Uktadanie do snu, w: eadem, Zabici czasem dtugo stoja, Wrocław 1995, s. 29. 
Pierwsza strofa jest introdukcją sytuacji, zanim pojawi się właściwa wypowiedź osoby usypiającej. Wstępny obraz stanowi odwrócenie zwykłych relacji: teraz to dzieci usypiają matki w niesprzyjającej aurze nocy (w wierszu zastosowana jest personifikacja nocy jako kobiety w sukni z sopli, jej obecności towarzyszą złowrogie odgłosy). Jednak kołysanka „w drugą stronę nie śpiewa”, podobnie opowiadanie baśni też staje się niemożliwe. Zamiast nich pojawia się krótki metaforyczny opis — reminiscencja negatywnych wydarzeń. Wiersz Janko jakby wspiera tendencję „resetowania pamięci” widoczną w poezji Ferenc. Surogatem kołysanki staje się krótka narracja (liryczna).

W innym wierszu autorki Wierszy z cieniem usypiane dziecko obecne jest jakby potencjalnie, istotniejsze stają się jego losy projektowane przez matkę według określonego modelu. Można też nawet wątpić w faktyczną obecność dziecka przy matce, chociaż od śladów (po) jego obecności rozpoczyna się wiersz — i w kontekście tytułu (Zdrewniała kotysanka) można zobaczyć kobietę w fazie odrętwienia, samotną, która (nadal) „[...] siedzi/ w kącie kuchni podrygując noga/ i kiwa łbem matczynym/ nad pijanym czasem"18, kierując do (nieobecnego) dziecka słowa:

— śpij malusi śpij
ślepe oczka zmruż
moje szczęście głuchonieme
cóż

zanim się wyroi płeć

zanim zaczniesz pić i jeść

na zdobycznych stołach

zanim zagrasz w piekło-niebo

po cudzych stodołach

zanim wrócisz tutaj z guzowatą twarzą

z małym oczkiem wpuszczonym pod czoło

Antycypacja przyszłości dziecka wydaje się być oczywista, pewna jest rozwojowa zmiana i jej kierunek: od matki ku światu. Dezaktualizacji ulega matczyna supremacja, to świat przejmuje kontrolę nad dzieckiem i nawet jego powrót nie przywraca automatycznie dawnego porządku.

U Janko kołysanka służy również do ujawniania relacji między dwojgiem dorosłych. W wierszu Kotysanka dla starej żony bardziej chodzi o uśpienie czujności wy-

18 A. Janko, Zdrewniata kotysanka, w: ibidem, s. 21. 
szczególnionej w tytule postaci niż o faktyczny (zwłaszcza błogi czy krzepiący) sen. Z punktu widzenia mężczyzny pożądany wydaje się jakby hipnotyczny trans, w czasie którego możliwa byłaby uczuciowa czy nawet moralna indoktrynacja „starej żony”. Wyraźne ironiczne nacechowanie utworu bardziej jeszcze „oddala” utwór od ludowego wzorca:

Mój małżonek

wiecznie młody

pochyla się nad kołyską

na poduszce ja - pająk

Uśmiecha się tak samo

jak wtedy gdy byłam żoną — dzieckiem

jest dobry

mówi - nie umrzesz pierwsza

będę cię kołysał

aż twoja pamięć stanie się gładkim walcem

i nie będziesz musiała pamiętać o mnie

Tylko to jest dla mnie ważne

byś zapomniała a więc nie była samotna ${ }^{19}$

Właściwą kołysankę jako wypowiedź stanowią słowa mężczyzny, jakby cytowane przez „ja” liryczne, które — poddane usypianiu — udostępnia odbiorcy również swoje przemyślenia, fałszywie brzmiącą ocenę (,jest dobry”), a wcześniej — wstępne rozpoznanie sytuacji. O różnicy między małżonkami decyduje czas wpływający na przeobrażenia - wiecznie młody mężczyzna i poddająca się upływowi czasu kobieta, która ulega metamorfozie, sygnalizowanej w wierszu przez metafory apozycyjne (już nie „żona — dziecko”, teraz ,ja — pająk”). Kołysanie jest działaniem na świadomość i pamięć, a zapomnienie — jako stan wywoływany — ma być też antidotum na samotność. Wprawianie w stan otępienia, odrętwienia koresponduje z illinktycznością kołysanki ${ }^{20}$.

W połączeniu kołysanka-erotyk uwidocznia się potoczny związek snu ze sferą seksualną. W dwudziestoleciu międzywojennym motywy erotyczne łączył z kołysankami

19 A. Janko, Kotysanka dla starej żony, w: eadem, Koronki na rany, Gdańsk 1988, s. 69.

20 Maria Ostasz zastosowała do opisu wiersza paidialnego typologie dziecięcych gier i zabaw Rogera Callois i Jana Cieślikowskiego, oparte na kategoriach: mimicry, alea, agon i illinx,. Illinx oznacza tu repetycję elementów świata przedstawionego, odwzorowuje zabawy w kole, huśtanie. Autorka wzięła pod uwagę także kołysanki, które mieszczą się w paidii ukierunkowanej na zniewalanie. Zob. M. Ostasz, Od Konopnickiej do Kerna. Studium wiersza paidialnego, Kraków 2008. 
Emil Zegadłowicz, wcześniej obecne były w utworach młodopolskich. Subtelnie sygnalizuje je również Tadeusz Kubiak:

Leżeli obok siebie

gdy usypiały usta

przemawiali do siebie

kołysanką rąk

Leżeli obok siebie

gdy usypiały oczy

szukali swoich kształtów

pośród ciał niebieskich ${ }^{21}$

Dotyk ma tu również znaczenie komunikacyjne. Dwie strofy przedstawiają jakby chwilę tuż przed zbliżeniem i niedługo po nim. To, co doświadczone na jawie, staje się komponentem marzenia sennego, przenosi się w sferę snu, zyskującą kosmiczny wymiar.

Wśród utworów, w których adresatami kołysankowej wypowiedzi są dzieci, często bywają prawdziwie liryczne, ujawniające rozczulenie i troskę dorosłego, ale zdarzają się również kołysanki zawierające przestrogi, ostre pouczenia, groźby ${ }^{22}$. W dedykowanym córeczce wierszu Kotysanka Romana Chojnackiego powtarzanemu „śpij” towarzyszą krytyczne opisy nieprzyjaznego dziecku świata dorosłych — to rzeczywistość, w której „za progiem upadają wiary i nadzieje/ a mistrz ceremonii wyjmuje z kapelusza następną/ parę rąk”. Nie istnieją tu analogie między światem dzieci i dorosłych:

nie wyciągaj do nas rąk — w kieszeniach naszych płaszczy

prywatne gilotyny — śpij — twój czas jeszcze nie nadszedł —

śpij — kto śpi

nie

mówi

nie

krzyczy

nie

dławi się -

śpij

21 T. Kubiak, Kotysanka, w: idem, Poezje wybrane, wybór i oprac. K. Pieńkosz, Warszawa 1983, s. 48.

22 Alicja Ungeheuer-Gołąb dostrzega podobne akty mowy także w kołysankach adresowanych do dzieci, obok próśb i bajania wymienia obiecywanie, przekupywanie czy straszenie. Zob. A. Ungeheuer-Gołąb, Kotysanka, czyli sposób na spokój, w: eadem, Poezja dzieciństwa, czyli droga ku wrażliwości, Rzeszów 2004, s. 26-68. 
I nim słowo wypowiesz — pomyśl — ile stracisz z umiejętności mówienia ${ }^{23}$

Różnicowanie rzeczywistości ludzi dojrzałych i ich pociechy ustala granice między strefą bezpieczną i niebezpieczną, do której potomek nie powinien mieć zbyt wcześnie dostępu. Bycie wewnątrz domu, a potem snu zwiększa gwarancje bezpieczeństwa. Powstrzymanie dziecka przed niepotrzebną aktywnością zdradza bezradność dorosłych. Sen oznacza tu niewyróżnianie się, a po jego zakończeniu czujność, nieufność mogą okazać się przydatne w relacjach z innymi. Bycie we śnie jest również komunikowaniem się z otoczeniem i dojrzewaniem do wypowiedzi (nie zawsze fortunnej) na jawie.

Małgorzata Gołąbek jest autorką Piosenki rodzacej, stanowiącej pierwszą kołysankę dla przychodzącego na świat dziecka. Zawarte w niej uspokajanie dziecka informuje też o obawach matki i tęsknocie za naturalnością, prywatnością ważnej chwili:

\author{
Luli luli maluśki \\ wyślizgnij się po cichu \\ Nie płacz \\ życie najlepiej zaczynać bez szmeru \\ Ta krew jest twoja i moja \\ posmakuj ją i poznaj \\ Będziesz jej jeszcze musiał oglądać bardzo wiele \\ Luli luli bądź cicho \\ a może nam się uda \\ może nikt nie usłyszy \\ może nie zauważą \\ Nie przyjdą nie zapiszą nie zmierzą cię nie zważą \\ I urodzisz się wolny \\ wszak zdarzają się cuda ${ }^{24}$
}

Intymność jest tu ograniczona wyłącznie do kontaktu matki i dziecka. Brak rejestracji danych po porodzie oznaczałby też wolność, szansę uniknięcia medycznych i administracyjnych zabiegów. Dziecko mówi w takich utworach „sobą”, swoją obecnością, bezbronnością, jego osoba jest komunikatem dla dorosłych — pozawerbalnym, opartym na atawistycznych skłonnościach i reakcjach.

23 R. Chojnacki, Kotysanka, w: Poeta jest jak dziecko. Nowe Roczniki. Antologia, wybór i oprac. M. Chrzanowski, Z. Jerzyna, J. Koperski, Warszawa 1987, s. 68-69.

${ }^{24}$ M. Gołąbek, Piosenka rodzacej, w: Poza stowa. Antologia wierszy 1976-2006, wstęp, wybór i red. T. Dąbrowski, posłowie M. Stala, Gdańsk 2006, s. 47-48. 
Podobny kontekst można odnaleźć w „porodowej” kołysance Joanny Kulmowej, w której poetka wykorzystuje mitologiczne tło. Małżonka króla Priama, świadoma niebezpieczeństwa i pragnąca ochronić syna, zwraca się do nowonarodzonego Parysa: „Boś nie w cudzym boś w moim powstał łonie/ Co tam/ jeśli ziemia od ciebie zapłonie"25. W wypowiedzi podmiotu — nietożsamego z małżonką władcy — powtarza się: „luli”, „luli lu”. Kulmowa z jednej strony przywraca królowej Troi ludzkie, naturalne cechy, z drugiej — archetypizuje matkę w relacji z dzieckiem („Nie inaczej chwalić będzie niebiosa/ kainowa matka/ i Herostratesa/ i Attyli”26).

Nawiązywanie do wzorców ludowych w kołysance literackiej jest jak powrót do źródeł gatunku. Paralelizm składniowy, jako jedna z cech utworów ludowych, występuje w Kotysance Anny Kamieńskiej. Działania matki i usypianego syna układają się w symetryczne ciągi charakteryzujące osoby. Pierwszy wers każdej strofy w niezmiennym kształcie („Mama syna kołysała”27) i drugi, zawsze o innej treści, dopełniający tę informację - poprzedzają zmieniający się opis zachowania usypianego bohatera, będący reakcją na konsekwentne, a nawet uporczywe usypianie przez rodzicielkę. Ambiwalencja uczuć i zachowań, podkreślana przez układ wersów i sens wiersza, obrazuje również proces dojrzewania najpierw synka-chłopca, potem synka-mężczyzny, który ostatecznie spełnia zapowiadane czyny (w kolejnych strofach: „Idę pole orać!”; „Idę do roboty!”; „Idę na wojenkę!”; „Synek porwał czapkę, buty,/ Z kołyski wyskoczył”). Czułość, przeradzająca się w nadopiekuńczość, a nawet zaborczość matki i konstatacje syna tworzą kontrastujące ze sobą obrazy. Zdrobnienia użyte w utworze (słowa matki, ale i syna: „Idę na wojenkę!”) budują komizm słowny i sytuacyjny.

Po wzorce ludowe sięga też Witold Dąbrowski. Na tle jego poezji traktującej bardzo serio „dekalog polski przenoszony z dziada na ojca, z ojca na syna” ${ }^{28}$, rejestrującej i powtarzającej bohaterskie słowa i gesty wcześniejszych pokoleń, tradycja folklorystyczna stanowi teren artystyczno-literackich trawestacji:

Przykląkł anioł u strugi,

u strugi,

pacierz zmówił niedługi,

niedługi,

hej!

25 J. Kulmowa, Kotysanka matczyna, w: eadem, Wiersze wybrane 1954-1979, Warszawa 1988, s. 301.

26 Ibidem.

27 A. Kamieńska, Kotysanka, w: eadem, Dębowa kotyska, Warszawa 1967, s.

28 A. Mandalian, Wstęp, w: W. Dąbrowski, Poezje wybrane, wstęp i wybór A. Mandalian, Warszawa 1983, s. 10 . 


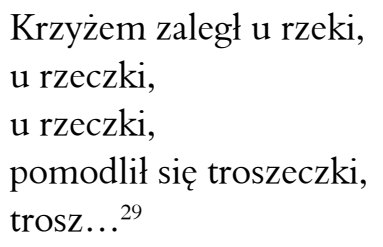

Dąbrowski modyfikuje topos anioła-stróża, pilnującego również dobrego snu. Podejmująca wędrówkę postać otrzymuje komiczny rys.

Codzienność, w której realizuje się kołysanka, została wykorzystana w utworze Ernesta Brylla. Liryk, pochodzący z tomu Sadza wydanego w 1982 roku, stanowi zbiór życzeń dotyczących pozytywnej zmiany fizycznej otoczenia podmiotu — mieszkania, wielorodzinnego domu i miasta, bo taki kierunek, amplifikujący przestrzeń (z wnętrza na zewnątrz), jest tu sugerowany. Siermiężna polska rzeczywistość i rozwiązania architektoniczno-urbanistyczne z lat, w których wiersz powstawał (projektowanie domów, jakość surowców budowlanych, zagospodarowywanie przestrzeni), stanowią wyraźne tło i jednocześnie temat kołysankowego komunikatu. Dla podmiotu ważne okazuje się przywracanie atmosfery domu, ujawnia się potrzeba schronienia, ale przede wszystkim własności, prywatności, odrębności. Czterostrofowa Kotysanka domowa Brylla składa się z szeregu próśb kierowanych do domowych sprzętów i mieszkania. Ciąg apostrof, jednolity charakter aktów mowy, zastosowane w tekście rymy krzyżowe i regularny ośmiozgłoskowiec podkreślają monotonię egzystencji:

Niechaj w rurach nic nie płacze

Niechaj dym odpłynie z miasta

W oknach krzywych jak zły pacierz

Niechaj błyśnie dobra gwiazda ${ }^{30}$

Praktyki życia codziennego i zwyczajne działania jednostki znalazły się w ostatnich dziesięcioleciach w centrum badań kulturowych — głównie za sprawą prac Michela de Certeau ${ }^{31}$. Według francuskiego badacza nawet zinstytucjonalizowane sposoby oddziaływania na człowieka, modelując jego percepcję rzeczywistości i determinując radzenie sobie w niej, zawsze prowadzą do indywidualnego systemu definicji, wytworzonego w procesie nabywania doświadczenia. Dobrą ilustracją takich tez mogłaby

\footnotetext{
29 W. Dąbrowski, Kotysanka, w: idem, Poezje wybrane..., op. cit., s. 68.

${ }^{30}$ E. Bryll, Kotysanka domowa, w: Poezja naszego wieku. Antologia wierszy publikowanych po 1918 roku, wybór i oprac. W. Kaliński, wyd. I, Warszawa 1989, s. 422.

31 Zob. M. de Certeau, L'Invention du quotidien, t. I: Arts de faire, wyd. II, Paris 1990. O poglądach Certeau mowa jest również w kontekście badań kulturowych, w: A. Burzyńska, M. P. Markowski, Teorie literatury XX wieku. Podręcznik, Kraków 2006, s. 519-548.
} 
być poezja Józefa Barana. Niektóre wiersze poety sytuują się w bliskim kontekstowym sąsiedztwie Kotysanki domowej Brylla. Ujawnia się w nich kulturowy mechanizm modyfikujący osobę, dla której zakres zmian obejmuje akcentowane przez Certeau instytucje — od rodziny chłopskiej przez szkołę, postrzeganą z perspektywy dziecięcej i zawodowo-nauczycielskiej, i własne dojrzałe, rodzinne życie. Baran mówi o tym w cytowanym już utworze Mam dwadzieścia pięć lat, ale także w Kotysance ojca czy Czarnej kołysance. Ten ostatni wiersz łączy kołysankę z tanatologią: dzieciństwo i jego atrybut — baśń nieodmiennie znajdują swój smutny finał w starości, ostatnim etapie wszelkiej codzienności.

Określenie „czarna kołysanka”, znamionujące mroczny, ale i sarkastyczny charakter utworu, zostało użyte przez Dariusza Pawelca ${ }^{32}$ w analizie wiersza Adama Zagajewskiego. Specyficzną „antykołysankę” poeta opublikował w tomie Ptótno, rozpoczyna się ona słowami:

Nie zaśniesz dzisiaj. Tyle blasku w oknie.

Sztuczne ognie rosną nad miastem.

Nie zaśniesz, za dużo się zdarzyło.

Książki czuwają nad tobą, ustawione w rzędy.

Będziesz długo myślał o tym, co się stało

i czego nie było. Nie zaśniesz dzisiaj.

Zbuntują się twoje różowe powieki,

będziesz miał oczy czerwone, piekące,

i serce spuchnięte od wspomnień.

Nie zaśniesz. $[\ldots]^{33}$

Podmiot liryczny, wyposażony w wiedzę na temat stanu adresata, komunikuje mu jego przyszłą sytuację. Roztacza negatywne wizje, utwierdza go w przekonaniu, że wszelkie próby zaśnięcia będą bezskuteczne. Zewnętrzny świat ma tutaj przewagę nad wewnętrznym światem lirycznego „ty”, przykuwa jego uwagę, nie pozwala się wyciszyć, natrętnie powraca i dominuje. Zwrot: „Nie zaśniesz” powtarza się w nagłosie i wygłosie różnych wersów, także w połączeniu z „dzisiaj” i ,już nigdy”. Językowa rekurencja wzmaga niepokój, pogłębia bezsenność, działa więc tu specyficznie „w drugą stronę”, wypowiedź podmiotu psychicznie dręczy i osacza adresata. Znamienne w tym kontekście jest również otwarcie encyklopedii i pamięci — zamiast zamknięcia. Przestrzeń

\footnotetext{
32 Dariusz Pawelec przypomina, że określenia „czarna kołysanka” użył Zagajewski w wierszu Starszemu bratu z tomu Pragnienie (1999); zob. D. Pawelec, „Czarna kotysanka”. Możliwości znaczenia gatunku na przyktadzie wiersza Adama Zagajewskiego „Kotysanka”, w: Tkanina. Studia, szkice, interpretacje, red. A. Węgrzyniak, T. Stępień, Katowice 2003, s. 125.

33 A. Zagajewski, Kotysanka, w: idem, Wiersze wybrane, red. R. Krynicki, Kraków 2010, s. 132.
} 
miasta, pomieszczenie, w którym przebywa pragnący zasnąć, przestrzeń jego ciała to główne motywy i tematy pulsujących obrazów. Bodźce (światła, dźwięki) wpływają na intensywny ruch myśli — zmuszają „ty” do aktywności, jaką jest spacer w parku. Zagajewski kreśli sytuację skazanego na całonocną bezsenność intelektualisty, spadkobiercy dawnych poetów i uczestnika współczesnej cywilizacji. Jak trafnie zauważa Pawelec:

Wiersz Adama Zagajewskiego przeczytany w gatunkowej perspektywie „czarnej kołysanki” wydaje się oddalać tę twórczość od możliwości interpretacji w duchu jednoznacznej ,jasnej” afirmacji „bogactwa świata” czy „zachwytu różnością". ${ }^{34}$

Adresat literackiej komunikacji w wierszu Julii Hartwig nie jest bezpośrednio identyfikowalny. To człowiek z doświadczeniem życiowym, do którego zwraca się „ja” mówiące:

Śpij Nic nie mam ci do ofiarowania prócz zmór i widm które się jawią w czas czuwania

Śpij o śpij Lecz przedtem zawrzyj z diabłem pakt że będzie pusty sen jak plac przed nocną zbiórką cieni

[...]

A jeśli już nie pusty — niechaj będzie sen

spełnieniem tego co jest w tobie najtajniejsze

niechaj nadrobi ból zbyt wcześnie ukojony

[...]

Śpij Wejdź w tę wodę zmąconą i ciemną

w której się obraz kołysze i łamie

i w której tonąc odnajdujesz słowa

co po zbudzeniu są zwykłą błyskotką ${ }^{35}$

U Hartwig dominuje negatywna poetyka braku i zaniechania. Nawet wyliczone miejsca i przestrzenie, które mogłyby wypełnić senne obrazy lub przynajmniej stanowić ich tło — zostają zanegowane jako powtarzalna sceneria, sytuacje i zdarzenia o skryptowym i schematycznym charakterze, przechowywane w umyśle i uruchamiane pod wpływem określonych bodźców. Według podmiotu konieczne jest modelowanie zawartości marzeń sennych, ich „remanent” — sen ma być „pusty”, niezapamiętany lub kompensujący braki na jawie. Sen zachowuje tu swoje wodne kolokacje, a akwatyczna wyobraźnia wspiera oniryczną. Widzenie lub niewidzenie we śnie stanowi w poezji

34 D. Pawelec, „Czarna kotysanka”..., op. cit., s. 129.

35 J. Hartwig, Kotysanka, w: eadem, Wiersze wybrane, red. R. Krynicki, Kraków 2010, s. 225. 
Hartwig konsekwencję przyjętych reguł percepcji świata i poznania zmysłowego, opartych na ograniczonych możliwościach ludzkiego oka i pamięci, stąd w jej twórczości widmowy i powidokowy status i byt kreowanych obrazów. Na przykład metafora miasta-widma pojawia się w utworach poetki wielokrotnie, niektóre wizje powracają wręcz obsesyjnie ${ }^{36}$ właśnie we śnie, który „kpi ze zmysłów”.

Sytuację gatunku w liryce współczesnej można określić jako rozpaczliwą niemożność (bo nie dezaktualizację) kołysanki przy jednoczesnym jej pragnieniu, dążeniu do niej i do stanu, jaki ona ewokuje. Kołysanka to synonim spokojnego życia, pełnej ataraksji. W tym sensie jawi się jako pożądany akt mowy, potrzebna zapowiedź zmiany świadomości, powrotu do źródeł, kompensacji. Zgromadzone przykłady pokazują sposoby maskowania gatunku — przez „fuzję form”, przekształcenia strukturalne i semantyczne, zmianę funkcji tekstu. Nadal gatunkotwórcza pozostaje rola sytuacji (,ja” zwracające się do „ty” z określoną intencją i w określonym celu), tyle że sytuację tę (podobnie jak inne czynniki — zasypianie, sen) należałoby w wielu utworach rozumieć metaforycznie. Kołysanka stale buduje nowe koneksje genologiczne ${ }^{37}$, poszerzając swoje transgatunkowe możliwości, w tym sensie gatunek pojmowany jako wiązka cech z pewnością ułatwia transpozycję.

\section{Katarzyna Wądolny-Tatar, Masking species. Lullaby in contemporary poetry}

Lullaby, used as a form of contemporary poetry, loses its real, situational references, which was keeping in the folk literature and partly in the literature for children. Transfer of the speech genre in the realm of literary means an increased degree of metaphoricalness of communication. Lullaby as transgenre enter into connections with a threnody, an elegy, lament, haiku (e.g. in poetry of Eugeniusz Tkaczyszyn-Dycki, Wojciech Kass, Zbigniew Herbert). Lullaby as a occasional literature is also understood otherwise - a species is becoming an opportunity to present themselves entity, indicate antinomity of the world, genological camouflage, though its relationship with the dream themes still exists. Folk patterns are undergoing artistic and literary modifications, structural and semantic transformations, and the function of text is changing (e. g. in poetry of Teresa Ferenc, Anna Janko, Anna Kamieńska, Ernest Bryll, Józef Baran, Julia Hartwig, Adam Zagajewski).

\footnotetext{
${ }^{36}$ Sześciowersowy fragment utworu To wszystko nie zostato stworzone dla ciebie (w: J. Hartwig, Wiersze amerykańskie, Warszawa 2002, s. 26) funkcjonuje jako osobny wiersz pt. Widziatam (ibidem, s. 79; a także w: eadem, Bez pożegnań, Warszawa 2004, s. 85).

37 Kołysanka w kulturze współczesnej wzbudza też aktualnie zainteresowanie badaczy. Zob. A. Jeziorkowska-Polakowska, „Pieśni zaklęte $w$ dwa języki...”. O kotysankach polskich, żydowskich i polsko-żydowskich (1864-1939), Lublin 2010; B. Stefaniak, Od lipowej kolebeczki do „kotyski na srebrnych nowiach” — uwagi o jezzku kotysanki, „Pamiętnik Literacki” 2011, z. 1, s. 155-177.
} 